Available online at: https://researchsynergy.org/ijrse

International Journal of Research in STEM Education (IJRSE)

ISSN 2721-2904 (Online) | 2721-3242 (Print)

Volume 3 Number 2 (2021): 28-36

\title{
Perception on the Adoption of WhatsApp for Learning amongst University Students'
}

\author{
Abdullahi Ismaila Abubakar'1 \\ ${ }^{1}$ Sokoto State University, Nigeria
}

\begin{abstract}
Technological advancement in this era boosted e-learning. E-learning is the privilege in which students can learn in respective of time and place or distance. Social media are websites created to disseminate information between an individual/group of people through the use of emerging technology. Web 2.0 technologies are among the technological innovations used for social media like smartphones and computers, just to mention a few. People interact with one another in respect of time, location, or distance for exchanging pleasantry, new ideas, or materials. This paper was guided by three objectives that are based on usefulness, ease of use, and attitude of students of higher institutions of learning. Three research questions. The researcher used a descriptive survey research design in the study. The researcher used the qualitative method with the use of individual interviews for data collection. A random sampling technique was employed to select the sample. The entire sample numbers was 10 . The instrument used for data collection was data-blank. Coding system was employed to gather and interpret data. The results indicated that the majority of students used WhatsApp for learning. The poster that WhatsApp is very easy to operate for learning and shows that students' attitude towards the use of WhatsApp for learning is positive. The research manifested that WhatsApp may be accepted as an instructional tool in teaching and learning.
\end{abstract}

Keywords: WhatsApp; Learning; social media; E-learning.

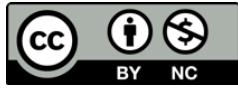

This is an open access article under the CC-BY-NC license.

\section{INTRODUCTION}

In this technological advancement era, e-learning is everywhere. E-learning is the privilege in which students can be able to learn in respective of time and place or distance. Social media are websites created for the purpose of dissemination of information between an individual/group of people through the use of emerging technology. Web 2.0 technologies are among the technological innovations used for social media like smartphones, computers just to mention but a few. People interact with one another in respect of time, location, or distance for exchanging pleasantry, new, ideas or materials. It has been observed by the researcher social media have become part of student life. The majority of them use social media for one reason or for the other. WhatsApp applications have become important as they serve as platforms for users to interact and relate with their peers; social networks are now being seen as learning platforms or communities that could be utilized to enhance student engagement and performance. A number of researchers have found several positive outcomes in online community engagement among students and their peers (Kaitibi, Nyelenkeh, Tunde, Musa, and Jalloh, nd).

It is amazing how the WhatsApp platform became part and parcel of human activities; WhatsApp is one of the social media applications that can let you communicate and disseminate information to peers, family, colleagues, mates, etc. WhatsApp can be possible through the use of a smartphone, iPhone, laptop, etc with a network connection. WhatsApp is a mobile application used for instant

Corresponding author

abdullahi.ismailabubakar@ssu.edu.ng

DOI: https://doi.org/10.31098/ijrse.v3i2.680

Research Synergy Foundation 
messaging purposes to replace the normal phone short messages (SMS) because of its capacity to send a large volume of messages and media files, unlike SMS (Sandra \& Nkeiruka, 2018). WhatsApp came into existence in the year 2009 and has become the most popular social media application used by mostly young people for communication (Sandra et al., 2018). One can install WhatsApp from Google play store or an apple store into their emerging technology and get access to the application. Something interesting about the use of WhatsApp is that when you install the application, you will open it, and they will direct you to register with them (creation of an account); after that, you will be visible to your contacts in the smartphone that are using the application. As such, the users can start sending and sending information between them. Through WhatsApp, users can send written, audio, or audio-visual messages individual or group chat using an internet connection or wireless/Wi-Fi. Brian Acton and Jan Koum purposely created WhatsApp in 2009 to make communication and the distribution of multimedia messaging more easily and faster; much as the application brings us so many benefits, it has also got it flaws that are currently causing harm than good among the students today, in cognizance of the rate at which our youth are up to social media, there is the need to educate them on its advantages and disadvantages in their performance accordingly (Baburao, 2018).

The use of the WhatsApp application by the students may bring many benefits to them; they could use it to pass information relevant to their academic activities, send learning material, etc. The two hundred level students of curriculum studies they are many, they are about 447 students' the value allocated to them for lecture may not be conducive for them to take lectures because the population is too much and the majority of them own a smartphone, and they may use WhatsApp application for learning or for other purposes. WhatsApp Messenger can be used as a learning media besides as a communication tool; it makes the teacher and the students easy to communicate and discuss reading material before going to the class to improve students' reading comprehension. WhatsApp is very easy and cheap to apply in teaching reading comprehension because the students have been familiar with WhatsApp. The steps using WhatsApp in teaching reading comprehension are setting the rules, creating a unique name for the WhatsApp group, starting the reading comprehension activity, and giving them feedback (Napratilora, Lisa, and Bangsawan, 2020).

This research will serve to call the attention of both teachers and students of higher institutions of learning that WhatsApp could be used for teaching and learning purposes by assessing usefulness, ease of use, and attitude of students in higher institutions of learning.

\section{STATEMENT OF THE PROBLEMS}

The researcher observed that the majority of tertiary students in Sokoto State-owned web 2.0 network provider, specifically, the smartphone, which can enable you to install WhatsApp application for sending and receiving short messages. These messages could be written, audio, or video clips. It has not known whether or not the students use this WhatsApp application for learning purposes. If these students are not using this WhatsApp for learning in the future, our teachers, curriculum planners, and curriculum implementers would be analog. Some students hardly use WhatsApp because of its mode of operation. Such students usually find it very difficult to operate and use such applications for academic activities, for instance, accessing a network, installation Apps, receiving and sending messages both audio and video, downloading files become quite tasking for them, and it could not be possible to used WhatsApp without knowing how to operate it, as such they may not use it for academic activities. Despite the use of WhatsApp among the students, some may hardly use it for their learning activities because of its mode of operation, for example, accessing the network, 
installation of Apps, browsing, downloading (audio and video messages), sending and receiving messages become quite tasking for them, and it could not be possible to used WhatsApp without knowing how to operate it, as such they may not use it for academic activities.

Students become addicted to their smartphones, and social media be their favorite applications used by them frequently, like WhatsApp, Facebook, 2go, Instagram, Twitter, Imo, Snapchat, Telegram, Ayoba, Tiktok, Palm chat, Whatpad, Likee, etc., this is manifesting us that our future teacher, curriculum planners, and curriculum implementers may not be able to impart knowledge, plan curriculum and implement curriculum to the younger ones because they didn't use the technology appropriately. However, from their attitude, it is not known whether or not they use WhatsApp for the enhancement of their academic activities.

This research aims to investigate the usefulness, ease of use, and attitude of Students' adoption of WhatsApp for Learning.

\section{OBJECTIVES OF THE STUDY}

The objectives of this study are to:

1. Find out the perceived usefulness of WhatsApp by the Students' of the University.

2. Examine the extent to which Students perceived ease of use of WhatsApp for academic purposes.

3. Examine Students' attitudes towards the use of WhatsApp for the improvement of their learning.

\section{RESEARCH QUESTIONS}

The following are the research questions:

1. How do the students of the University perceive the usefulness of WhatsApp?

2. To what extent to which students of the University perceive ease of use of WhatsApp for academic purposes?

3. What is the students' attitude towards the use of WhatsApp for study?

\section{LITERATURE REVIEW}

Literatures have been reviewed as stated; Bello (2015) in his research "effects of multimedia instructional formats on senior secondary school students' achievement and retention in agricultural science in Minna educational zone, Niger state, Nigeria" he used quasi-experimental pre-test post-test control group design. The experimental groups were taught with multimedia instructional formats, and the control group was taught using the lecture method. The finding showed that students in the experimental group achieved significantly better than their counterparts in the control group. Social media tools are available and often utilized by Ekiti state university during their instructional delivery (Bamidele, 2016).

WhatsApp is useful, easy to use, easy to learn, and provides satisfaction (Widodo, 2019; Barhoumi, 2015). Therefore, WhatsApp can implement in the learning system. Barhoumi (2015); Hezekiah \& Patrick (2016); Gertrude \& Anum (2016); Anthony, Damola \& Joel, (2016); Yahya (2018); Annamalai (nd) their findings show teachers and students have a positive attitude towards the use of WhatsApp application for educational activities. That WhatsApp was used for sharing study materials in the form of links, notes, assignments, and coursework; it was used to enhance communication between teachers and students; students used WhatsApp environment to help one another and to cater for anywhere anytime learning. The above review indicated that the WhatsApp application is used for 
enhancing teaching and learning; the application is saved as a tool for passing information/materials between student and their mate or teacher and his/her students, which enables them to access them so fast and easy.

Itighise (2016), in his research, revealed that lecturers lack expertise skills in the use of innovative teaching methods and interactive whiteboard utilization for course content delivery; they are addicted to the conventional teaching method. Young people tend to spend more time on social media, and that familiarity with social media diminishes with aging. It was concluded that social networking sites are yet to be maximally employed for instructional purposes among students of the National Open University of Nigeria (Ogunmakin \& Adekunle, 2016). WhatsApp has a profound negative impact on students and adversely affects their education, behavior, and routine lives. It messes up much of the study time of students and distracts them from completing their assignments, and this app has been found to be highly addictive (Rabbani (2015); Bhatt \& Arshad (2016); Irfan \& Dhimmar (2019). This review shows us that lecturers of higher institutions of learning use WhatsApp for one thing or for the other, but they lack the skills to use it for teaching purposes; students use the application for less important things like chatting with their peers, which serves as entertainment purposes; which make them reluctant to do their academic activities.

Based on the literature reviewed so far, I didn't lay my hand on research on the usefulness, ease of use, and attitude of the adoption of WhatsApp for learning amongst the students of higher institutions in Sokoto State, Nigeria. There are different results/findings by different researchers that conducted research based on the adoption of WhatsApp for learning; some indicated that WhatsApp is one of the apps to be used as teaching and learning tools, while some said is not worthy as teaching and learning tool rather a source of class distraction. There is a need for research on Perception on the Adoption of WhatsApp for Learning amongst higher institutions in Sokoto State, Nigeria. This is because the findings of the research will now give a general overview regarding the adoption of WhatsApp for learning amongst university students in Nigeria. This makes the study work different.

\section{RESEARCH METHODOLOGY}

Descriptive survey research design was used in this study. A qualitative method was employed for data collection. The target population is the Two Hundred Level Curriculum and Instruction Studies I Students' of Sokoto State University, Nigeria. However, the Random sampling technique was employed to select the sample; the total populations of the sampled students were 10; the data for the qualitative sample will be small. The rationale behind the use of the qualitative method is to reach and get data from the small group and handle a huge amount of data from them, shown in Table 1.

Table 1: Two Hundred Level Curriculum Studies Students' of Sokoto State University, population and sample size:

\begin{tabular}{llll}
\hline S/N & Sokoto State University & Population & Sample Size \\
\hline $\mathbf{1 .}$ & Male Students & 244 & 05 \\
2. & Female Students & 203 & 05 \\
& Total & $\mathbf{4 4 7}$ & $\mathbf{1 0}$ \\
\hline
\end{tabular}

\section{INDIVIDUAL INTERVIEW}

Information was gathered through a data-blank from the respondents. 10, Two Hundred Level Curriculum and Instruction Studies I Students' of Sokoto State University were selected (five male and 
female each). The questions that the respondents responded to were analyzed one after the other using code, summarizing the key points of the information gathered through respondents to make the researcher arrive at the right decision/interpretation.

\section{DATA ANALYSIS OF INDIVIDUAL INTERVIEW}

Coding system was used to gather and interpret data. The individual interview was held with ten (five male and female each) Two Hundred Level Curriculum and Instruction Studies I Students' of Sokoto State University, which were selected at random from the University. The use of a coding system will allow the researcher to use numbers or alphabet that can enable him/her to collect data one after the other and proceed to selection and interpretation. Below are responses that were sampled of some respondents using coding; male students (A), female students (B).

The $460 \%$ of respondents find WhatsApp as a useful tool for learning; it is only $150 \%$ of respondents find WhatsApp not useful for learning. The result shows that the WhatsApp application is useful for learning (see table 2). This finding was in accordance with that of Bello (2015) and that of Bamidele (2016). The result is contrary to that of Ogunmakin \& Adekunle (2016), which shows social networking sites are yet to be maximally employed for instructional purposes among students of the National Open University of Nigeria.

Table 2: Usefulness of WhatsApp

\begin{tabular}{llll}
\hline S/N & Statement's & Yes & No \\
\hline 1 & Do you use WhatsApp? & 10 & 0 \\
& & $(100 \%)$ & $(0 \%)$ \\
2 & Did you use WhatsApp for learning? & 7 & 3 \\
& & $(70 \%)$ & $(30 \%)$ \\
3 & Did WhatsApp improve your learning activities? & 7 & 3 \\
& & $(70 \%)$ & $(30 \%)$ \\
4 & Did you find WhatsApp useful for learning? & 8 & 2 \\
& & $(80 \%)$ & $(20 \%)$ \\
5 & Did WhatsApp encourage you to read? & 7 & 3 \\
& & $(70 \%)$ & $(30 \%)$ \\
6 & Did you receive immediate feedback from your lecturers & 7 & 3 \\
& while using WhatsApp? & $(70 \%)$ & $(30 \%)$ \\
& & $(\mathbf{4 6 0 \% )}$ & $\mathbf{( 1 5 0 \% )}$ \\
\hline
\end{tabular}

The $590 \%$ of respondents find the WhatsApp application very easy to use; it is only respondent $100 \%$ of the respondents that find the WhatsApp application difficult to operate. The result indicated that WhatsApp application is very easy to use for learning (see table 4.3). This finding supports the earlier findings of Widodo (2019) and Barhoumi (2015).

Table 3 Ease to use

\begin{tabular}{llll}
\hline $\mathbf{S} / \mathbf{N}$ & Statement's & Yes & No \\
\hline 1 & Did WhatsApp available to you? & 9 & 1 \\
\hline
\end{tabular}




\begin{tabular}{|c|c|c|c|}
\hline & & $(90 \%)$ & $(10 \%)$ \\
\hline 2 & Is it easy for you to use WhatsApp for learning? & $\begin{array}{l}9 \\
(90 \%)\end{array}$ & $\begin{array}{l}1 \\
(10 \%)\end{array}$ \\
\hline 3 & $\begin{array}{l}\text { Did your interaction with WhatsApp clearly and } \\
\text { understandable? }\end{array}$ & $\begin{array}{l}9 \\
(90 \%)\end{array}$ & $\begin{array}{l}1 \\
(10 \%)\end{array}$ \\
\hline 4 & $\begin{array}{l}\text { Did you think you will be skillful using WhatsApp for } \\
\text { learning? }\end{array}$ & $\begin{array}{l}9 \\
(90 \%)\end{array}$ & $\begin{array}{l}1 \\
(10 \%)\end{array}$ \\
\hline 5 & $\begin{array}{l}\text { Did you need someone to assist you while using WhatsApp } \\
\text { for learning? }\end{array}$ & 9 & $\begin{array}{l}1 \\
(10 \%)\end{array}$ \\
\hline 6 & Did you use WhatsApp for learning alone? & $\begin{array}{l}9 \\
(90 \%)\end{array}$ & $\begin{array}{l}1 \\
(10 \%)\end{array}$ \\
\hline 7 & $\begin{array}{l}\text { Did you have adequate electricity for better use of } \\
\text { WhatsApp learning? }\end{array}$ & $\begin{array}{l}5 \\
(50 \%)\end{array}$ & $\begin{array}{l}5 \\
(50 \%)\end{array}$ \\
\hline & Percentage & $(590 \%)$ & $(100 \%)$ \\
\hline
\end{tabular}

On the students' attitude towards WhatsApp for learning use, respondent $280 \%$ agreed that the use of WhatsApp for learning would positively impact their learning. It is only respondent $20 \%$ indicated negative attitudes towards online learning use for learning. The result shows that the attitude of students on the use of WhatsApp for learning is positive (see table 4). This finding is in line with previous studies by Barhoumi (2015); Hezekiah \& Patrick (2016); Gertrude \& Anum (2016); Anthony, Damola \& Joel (2016); Yahya (2018); Annamalai (nd). The research conducted by Rabbani (2015), Bhatt \& Arshad (2016), Irfan \& Dhimmar (2019) revealed that WhatsApp has a profound negative impact on students and adversely affects their education, behavior, and routine lives.

Table 4 Attitude of students towards the use of WhatsApp

\begin{tabular}{llll}
\hline $\mathbf{S} / \mathbf{N}$ & Statement's & Yes & No \\
\hline 1 & Did you like to use WhatsApp for learning? & 10 & - \\
& & $(100 \%)$ & \\
2 & Using WhatsApp for learning, it's a good idea? & 10 & - \\
& & $(100 \%)$ & \\
3 & Did the use of WhatsApp for learning, it's a bad idea? & - & 10 \\
& & & $(100 \%)$ \\
4 & Did you appreciate the use of WhatsApp for learning? & 8 & 2 \\
& & $(80 \%)$ & $(20 \%)$ \\
& Percentage & $\mathbf{( 2 8 0 \% )}$ & $\mathbf{( 2 0 \% )}$ \\
\hline
\end{tabular}

\section{CONCLUSION}

The research uses a descriptive survey research. Qualitative method served as a mode for data collection; the populations of the study are the two hundred level students of Sokoto State University, Nigeria. The study shows that students of the universities use WhatsApp for learning; they find the application very easy to use for academic activities, and their attitude towards the use of WhatsApp for learning is positive. WhatsApp will play a vital role in promoting students learning if teachers' and students' get to know and utilize it as a learning tool; it's a huge privilege with this technological advancement which promotes students use of WhatsApp for learning very easy in a positive way, in 
future e-learning will be possible everywhere, WhatsApp will be used for teaching and learning purposes.

\section{REFERENCES}

Annamalai, N., (nd). Using WhatsApp to extend learning in a blended classroom environment. Teaching English with Technology, 19(1), 3-20, http://www.tewtjournal.org files.eric.ed.gov

Anthony, 0. 0., Damola, O. \& Joel, A. 0., (2016). Students' acceptance and attitudes towards using instructional mobile technology package in college of education in Osun state. Joel, L. A. (Ed.) Nigeria Association for Educational Media and Technology (EMTAN). Journal of Nigeria Association for Educational Media and Technology, 21, 1, 1, 122-136

Baburao, S. C., (2018). The impact of WhatsApp massager usage on students' performance. International Journal of Trend in Scientific Research and Development, 2456-6470

Barhoumi, C., (2015). The effectiveness of WhatsApp mobile learning activities guided by activity theory on students' knowledge management. Contemporary Educational Technology, 6(3), 221-238. www.files.eric.ed.gov

Bawa, N. \& Abdullahi, A., (2016). Using WhatsApp to extend learning into undergraduate students' digital lives: measuring its effects on academic performance in general studies. ATBU Journal of Science, Technology and Education, 4 (2), 2277-0011. https://www.researchgate.net/publication/335207659

Bamidele, 0. 0. \& Omoron, A. J., (2016). Social media: A veritable tool for effective instructional delivery in the tertiary institution for sustainable national development. Joel, L. A. (Ed.) Nigeria Association for Educational Media and Technology (EMTAN). Journal of Nigeria Association for Educational Media and Technology, 21, 1, 1, 225-237

Bello, A., (2015). Effects of multimedia instructional formats on senior secondary school students' achievement and retention in agricultural science in Minna educational zone, Niger state, Nigeria. A Master's Thesis in Educational Technology, Submitted to Postgraduate School, Federal University of Technology, Minna, Niger State-Nigeria. Published

Bhatt, A. \& Arshad, M., (2016). Impact of WhatsApp on youth: a sociological study. IRA-International Journal of Management \& Social Science. ISSN: 2455-2267, 4(2), 376-386. DOI: http://dx.doi.org/10.21013/jmss.v4.n2.p7

Bian, H. (2017). Mixed method research [PowerPoint slides]. Contact Information, Office: 1001 Joyner Library (room) 1006. Phone: 252-328-5428, Website: core.ecu.edu/statisticsresearch. https://dokumen.tips

Bisen, S., \& Deshpande, Y., (2016). An analytical study of smartphone addiction among engineering students: a gender differences. The International Journal of Indian Psychology. Issn; 23493429 (p), 4, (1) 81, http://www.ijip.in 
Creswell, J. W. (2014). Research design: qualitative, quantitative, and mixed methods approaches (4th ed.). Library of Congress Cataloging in Publication Data. Printed in the United States of America.

Gertrude, K. E. \& Anum, O., (2016). Enhancing tertiary education using social media. Joel, L. A. (Ed.) Nigeria Association for Educational Media and Technology (EMTAN). Journal of Nigeria Association for Educational Media and Technology, 21, 1, 1, 287-297

Hezekiah, B. B. \& Patrick, E. E., (2016). Responses of students' of Christian religious studies to challenges faced in utilization of social media for educational communication in Nigeria. Joel, L. A. (Ed.) Nigeria Association for Educational Media and Technology (EMTAN). Journal of Nigeria Association for Educational Media and Technology, 21, 1, 1, 238-263

Irfan, M. \& Dhimmar, S., (2019). Impact of WhatsApp messenger on the university level students: a psychological study. https://www.researchgate.net/publication/332093442

Itighise, A. E., (2016). Innovation in higher teachers' education: an imperative for achievement of sustainable national development. Joel, L. A. (Ed.) Nigeria Association for Educational Media and Technology (EMTAN). Journal of Nigeria Association for Educational Media and Technology, 21, 1, 1, 264-273

Kaitibi, D, B., Nyelenkeh, A. T., Tunde, E. T., Musa, A. Y. \& Jalloh, M., (nd). Impact of WhatsApp massager on the performance of students in tertiary institution in southern Sierra-Leone.

Napratilora, M., Lisa, H., \& Bangsawan, I., (2020). Using WhatsApp as a learning media in teaching reading. Prodipendidikan Guru Madrasah Ibtidaiyah STAI Auliaurrasyidin Tembilahan, 6 (2), ISSN: 2443-0021, e-ISSN: 2716-416

Ogunmakin, R. \& Adekunle, A. A., (2016). Access and use of social networking sites among students of National Open University of Nigeria. Joel, L. A. (Ed.) Nigeria Association for Educational Media and Technology (EMTAN). Journal of Nigeria Association for Educational Media and Technology, 21, 1, 1, 48-62

Rabbani, G. S., (2015). Impact of WhatsApp messenger on the university level students: a sociological study. International Journal of National and Social Sciences. ISSN: 2313-4461, 2(4), 118-125

Sandra, A. E. \& Nkeiruka, N. Q., (2018). WhatsApp utilization and academic performance of computer in university of Port-Harcourt. International Journal of Education, Learning and Development, $6,5,15-25$

Widodo, L., (2019). Users' perceptions of the WhatsApp usefulness in learning. Open Journal for Information Technology, 2 (1), 1-8. https://doi.org/10.32591/coas.ojit.0201.01001w 
International Journal of Research in STEM Education (IJRSE), Vol. 3 (2), 28-36

Perception on the Adoption of WhatsApp for Learning amongst University Students'

Abdullahi Ismaila Abubakar

Yahya, M. M., (2018). Social media in the classroom: WhatsApp a new communication tool for enhanced class interactions. Business Education Journal, 11(1), http://www.cbe.ac.tz/bej Retrieved on 03/06/2018 from pdfs.semanticscholar.org 